\title{
Tracheal stenosis in a Holstein cow
}

\author{
Franciéli Adriane Molossi ${ }^{1}$ iD Regina Tose Kemper $^{1}$ iD Bianca Santana de Cecco ${ }^{1}$ iD \\ Rafael Biondo Rosa ${ }^{1}$ iD Luciana Sonne ${ }^{1^{*}}$ iD David Driemeier ${ }^{1}$ (D)
} ${ }^{1}$ Setor de Patologia Veterinária, Universidade Federal do Rio Grande do Sul (UFRGS), 91540-000, Porto Alegre, RS, Brasil. E-mail:
lusonne@yahoo.com.br. "Corresponding author.

\begin{abstract}
Tracheal stenosis, also known as "Honker syndrome", is characterized by tracheal edema and hemorrhage, leading to partial obstruction of the lumen; therefore, death. Its etiology is not yet well elucidated. A 3-year-old Holstein cow, with a history of dyspnea, and a large amount of reddish foam flowing from the mouth and nose, had died after 10 minutes of clinical signs. Macroscopic examination revealed focally extensive hemorrhage and clot organization in tracheal mucosa extending to the submucosa, surrounded by well-differentiated fibrous connective tissue. In adjacent mucosa was observed moderate multifocal inflammatory infiltrate composed by lymphocytes and plasma cells, as well as moderate squamous cell metaplasia. The bacterial culture showed growth of contaminant and environmental bacteria and the RT-PCR to detect Herpesvirus 1 (BoHV-1) and 5 (BoHV-5) was negative. To the author's knowledge, this is the first report of tracheal stenosis in South America, as well as the first report of this condition described in a Holstein cow.
\end{abstract}

Key words: dairy cow, Honker syndrome, trachea, edema, hemorrhage.

Estenose de traqueia em uma vaca holandesa

RESUMO: A estenose traqueal, também conhecida como "síndrome de Honker", caracteriza-se pela formação edema e hemorragia na traqueia, causando obstrução parcial do lúmen e consequentemente morte dos animais. Sua etiologia ainda não está bem esclarecida. Descreve-se um caso de um bovino, fêmea de aptidão leiteira, três anos de idade com manifestação clínica de dispneia, e secreção de grande quantidade de espuma avermelhada pela boca e narina, e óbito após 10 minutos de evolução do quadro. No exame macroscópico, observou-se em traqueia área focalmente extensa de coágulo circundado por tecido conjuntivo na região dorsal, em áreas adjacentes havia espessamento da mucosa causado por edema e tecido conjuntivo. No exame microscópico observou-se em traqueia, hemorragia e coágulo em organização na submucosa estendendo-se para a mucosa, circundada por tecido conjuntivo fibroso bem diferenciado. Em mucosa adjacente, observou-se infiltrado inflamatório multifocal, moderado de linfócitos e plasmócitos e metaplasia escamosa do epitélio respiratório, multifocal moderada. Verificou-se no cultivo bacteriano que houve crescimento misto abundante somente de bactérias contaminantes e bactérias ambientais. Além disso, a técnica de RT-PCR para detecção Herpesvírus tipo 1 (BoHV-1) e 5 (BoHV-5) resultou negativa. Este foi o primeiro relato ao conhecimento dos autores, de estenose traqueal na América do Sul, bem como o primeiro descrito em bovino de aptidão leiteira.

Palavras-chave: vaca leiteira, Sindrome de Honker, traqueia, edema, hemorragia.

Tracheal stenosis, also known as tracheal edema and hemorrhage syndrome, was described in confined cattle (ERICKSON \& DOSTER, 1993; GAGEA et al., 2006; HENDRICK \& ABEYSEKARA, 2014) and recently in finishing pigs (SZEREDI et al., 2015). The disease is characterized by a partial obstruction of the tracheal lumen due to severe edema and mucosal and submucosal hemorrhage of the dorsal distal half of the trachea (CASWELL \& WILLIAMS, 2016; CLARK, 2004). Its etiology remains uncertain; however, it is attributed to noninfectious causes (ERICKSON \& DOSTER, 1993; CLARK, 2004). There was also no association of tracheal stenosis in confined cattle with other preexisting chronic airway or lung lesions. This disease is commonly associated with extenuating activities in heavy animals, in a dusty environment and hot weather (ERICKSON \& DOSTER, 1993; APLEY \& FAIT, 1998).

The syndrome is characterized by sudden dyspnea, cough, and respiratory stridor due to partial tracheal obstruction, which occasionally leads to death due to asphyxiation (CASWELL \& WILLIAMS, 2016). The respiratory stridor produced by severely affected animals originates from the clinical term of "Honker syndrome". In several cases, affected animals can be reported dead with few or no previous signs (ERICKSON \& DOSTER, 1993). In more chronic cases, submucosal fibrosis can be observed in the trachea (ERICKSON \& 
DOSTER, 1993). This study aimed to describe the epidemiological, clinical and pathological aspects of a case of tracheal stenosis in a Holstein cow, which in the authors' knowledge, is the first description of this disease in this bovine breed and the first description of the disease in South America.

A 3-years-old Holstein cow, from a 112-lactation lot in the city of Teutônia - RS, presented clinical signs of progressive weight loss, in the last months. In the winter, the animal started with respiratory difficulty, expelled a large amount of reddish foam from mouth and nostrils and died 10 minutes after the clinical signs began. The cattle spent half of the day in confinement in a concrete floor barn and the other half in ryegrass pasture (Lolium multiflorum), and the diet was complemented with corn silage, and pre-dried Tifton silage placed in feedlots.
At necropsy, it was observed pale mucosae and a moderate amount of blood in nostrils. In the distal third of the trachea, there was a focally extensive region of clot surrounded by fibrous connective tissue measuring about $6.0 \mathrm{~cm}$ of diameter, firmly adhered to dorsal mucosal. In adjacent areas of the clot, there was thickening of the mucosa constituted by edema and proliferation of connective tissue (Figure 1A e 1B). There was still a moderate amount of red foam in the tracheal lumen, which extended to bronchi. In adventitia was observed multifocal and moderate petechial hemorrhage.

The lungs did not collapse, they were red with multifocal moderate dark foci and nasal sinuses presented reddish mucosa. At the cut surface, the lung exhibited a moderate amount of liquid. Samples of all organs were collected and fixed in $10 \%$ buffered formalin. The formalin-fixed tissues were dehydrated

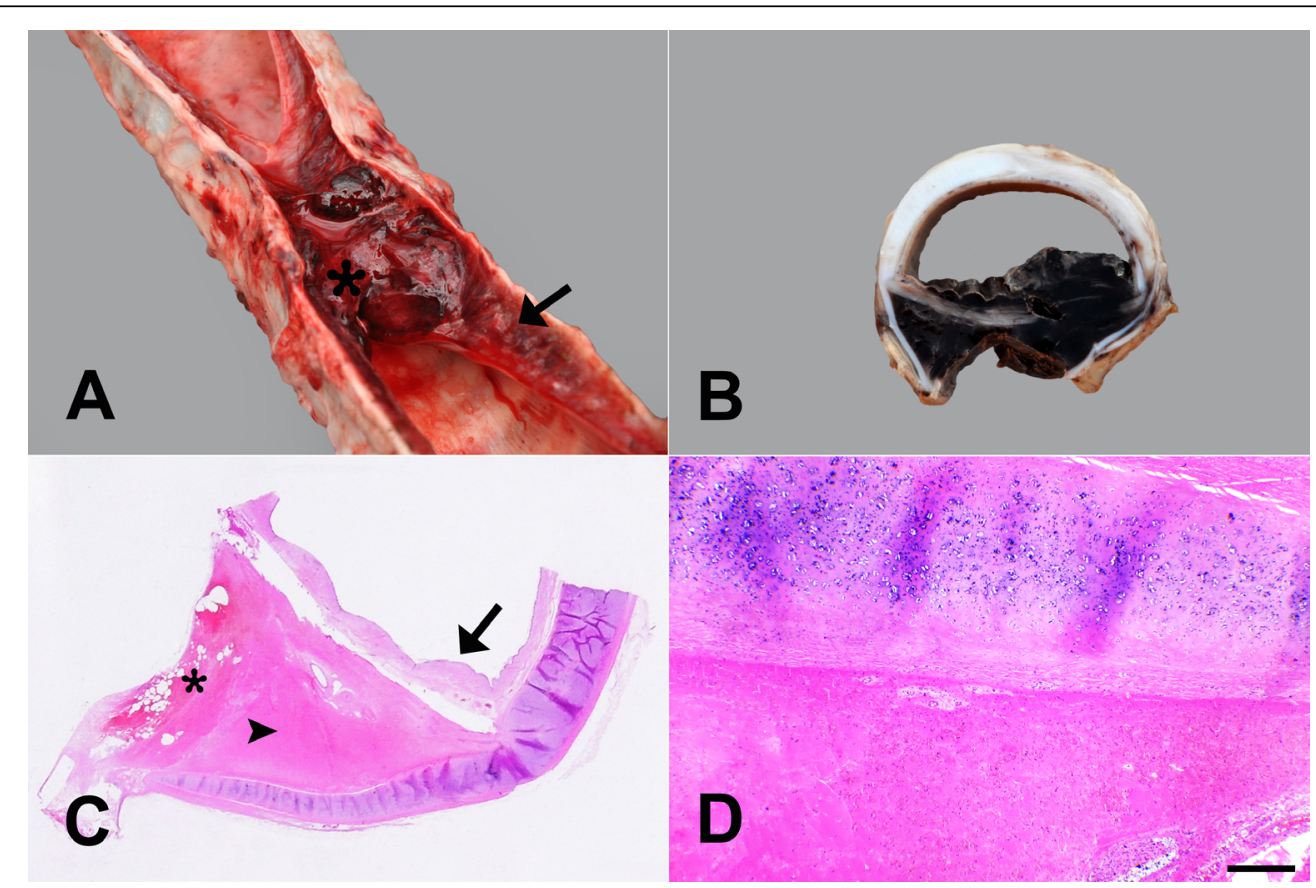

Figure 1 - Dairy cow with tracheal stenosis. A) Trachea with a focal area of a large clot surrounded by connective tissue measuring approximately $6.0 \mathrm{~cm}$ in diameter, attached to the mucosa in the dorsal region (asterisk). In areas adjacent to the clot there was thickening of the mucosa, which consisted of edema and proliferation of connective tissue (arrow). B) Cut surface of the tracheal region with clot and adjacent areas with thickening of the mucosa, characterized by edema and proliferation of connective tissue, fixed in $10 \%$ formalin. C) Sub macro of the trachea region with a proliferation of connective tissue (arrow) surrounding a focal area of extensive hemorrhage (asterisk) and deposition of a marked amount of fibrin (arrowhead). D) Proliferation of fibrous connective tissue between the tracheal cartilage and the formation of the clot with fibrin (HE, Bar $200 \mu \mathrm{m})$. 
in alcohol, embedded in paraffin wax, and 3-5 $\mu \mathrm{m}$ thick sections were then cut. The sections were dewaxed, stained with hematoxylin and eosin for routine histopathology, and examined with a routine light microscope.

Microscopically, it was observed in trachea, hemorrhage and an organized clot, from submucosa extending to the mucosa, surrounded by welldifferentiated fibrous connective tissue (Figure 1C e 1D). In adjacent mucosa, was observed inflammatory infiltrate composed by lymphocytes and plasma cells, as well as, squamous metaplasia of respiratory epithelium, with loss of cilia and neovascularization. In the lungs, multifocal could be noted as moderate hemorrhage and intra-alveolar edema, besides terminal bronchiole hypertrophy and alveolar smooth muscle proliferation. Nasal sinuses demonstrated accentuated and diffuse hyperemia, and discrete multifocal thrombosis. Other organs had no alterations.

Tracheal fragments were sent to the laboratory of microbiology and cultivated on Blood Agar (5\% sheep blood; Mueller Hinton, Kasvi ${ }^{\circledR}$, Brazil) and Macconkey Agar plates (Kasvi ${ }^{\circledR}$, Brazil) followed by aerobic incubation at $37{ }^{\circ} \mathrm{C}$ for 72 hours. Only contaminant and environmental bacteria were observed.

Another fragment of affected tissue of trachea was submitted to Reverse Transcrition Polymerase Chain Reaction (RT-PCR). The primers forward (PF 5' CGGCCACGACGCTGACGA 3') and reverse (PR 5' CGCCGCCGAGTACTACCC 3') were designed to target a $575 / 572 \mathrm{bp}$ fragment on BoHV-1 and -5 (nucleotides 873-1447 and 813-1384 from sequences accession nos. Z49223 and Z49224, respectively), as described by ESTEVES (2008). Both had a negative result.

The diagnosis of tracheal stenosis in a Holstein cow was based on epidemiological data, clinical signs, macroscopic and histopathological findings. The etiopathogenesis of this disease in cattle is not well elucidated, not being possible to relate with an etiological or preexistent illness of airway or lungs (ERICKSON \& DOSTER, 1993). In the present study, there was also no relation between infectious agents and disease to be considered, since RT-PCR and bacteriological analysis yielded negative results, especially for Bovine Infectious Rhinotracheitis. However, the normal commensal microbial flora of the cow could participate in the beginning or progression of the tracheal lesion (ERICKSON \& DOSTER, 1993).

In humans, tracheal stenosis is related to infectious pathogens, chemical and physical agents, in case of exorbitant respiratory distress and cough, lesion to the mucosa and posterior region of the trachea can appear (ERICKSON \& DOSTER, 1993). The tracheal membrane expands during inspiration and the lumen becomes rounded; in expiration, the membrane slightly projects itself to the lumen. This dynamic becomes dramatic during cough, when there may be significant invagination of the tracheal membrane in the lumen and even rupture of the membranous ligaments and muscles. However, if similar events happen to cows with aggressive cough, a repeated insult to submucosa may cause edema and tracheal hemorrhage (ERICKSON \& DOSTER, 1993). In this report, the clinical manifestation of cough was not observed, therefore, it was no possible to relate this clinical sign to lesions, despite those presented to be chronical due to the presence of fibrous connective tissue.

In the current study, we identified some factors that may have triggered the clinical disorder or even caused a cough eventually unnoticed. Despite being winter on the day and place where the case occurred, during the four days preceding the death of the bovine, the temperature reached $27^{\circ} \mathrm{C}$, and the average temperature in June was $16^{\circ} \mathrm{C}$ (ranging from $2{ }^{\circ} \mathrm{C}$ to $30^{\circ} \mathrm{C}$ ), and the average humidity was $70 \%$ (ranging from $42 \%$ to $98 \%$ ) (Nacional, Meteorology Institute - INMET). Purebred cattle from temperate climates have high requirements for thermal and stable comfort when raised in tropical or subtropical climates (BÓ et al., 2003). Holstein cows are estimated to require room temperature between 5 and $18^{\circ} \mathrm{C}$ for maximum expression of their genetic potential (MORAIS et al., 2008). Heat-stressed cattle tend to increase respiratory rate (FERREIRA et al., 2006). In our study, the cow was subjected to hot weather, as well as dusty places associated with walking to pasture, in accordance with the predisposing factors described (ERICKSON \& DOSTER, 1993; APLEY \& FAIT, 1998) that may have contributed to the development of the condition.

The trachea and adjacent structures may also be compressed by the upper edge of the troughs during feeding, resulting in localized hypoxia and tracheal mucosa necrosis (ERICKSON \& DOSTER, 1993). In the present study, it was found that the animals were fed in these feedlots in the confinement and may thus have contributed to the formation of a tracheal lesion. The cow also died rapidly after presenting severe dyspnea, and this information is in agreement with the literature (ERICKSON \& DOSTER, 1993; CASWELL \& WILLIAMS, 2016; GRIFFIN, 1998); however, due to visualization of fibrous connective tissue, is believed that the disease 
was chronic, which is also in accordance to literature (ERICKSON \& DOSTER, 1993). Besides, the lesions were characterized by edema and hemorrhage in the dorsal wall of the trachea, found on macroscopy and microscopy, as well as inflammatory infiltrate and squamous metaplasia of the epithelium, as previously described (ERICKSON \& DOSTER, 1993; SZEREDI et al., 2015; CLARK, 2004; ANDREWS \& KENNEDY 1997).

Cattle infected with BoHV-5 at the beginning of the clinical signs, often have serous nasal and ocular discharge that, with the evolution of the disease, becomes mucous and mucopurulent, signs that can be confused with infection with BoHV1 (RISSI et al., 2006; RISSI et al., 2007). Because of that, the differentials must include some lesions and diseases associated with the larynx and trachea of cattle, including tracheitis, especially caused by bovine herpesvirus type 1 and type 5 (RADOSTITS et al., 2000), which in this report resulted in negative for these agents. Also, inflammatory, ulcerative and papillomatous lesions of the larynx (JENSEN et al., 1981), and tracheal stenosis of calves (WATT, 1983; RINGS, 1995). The recommended treatment is the immediate application of corticosteroids. Antibiotic administration to affected animals is common; although, neither necessary nor effective for this condition (GRIFFIN, 1998; APLEY \& FAIT, 1998). The cattle in question did not receive any kind of treatment since the death was unexpected.

The tracheal stenosis that occurred, in this case, led the cattle to death due to asphyxia by edema formation and tracheal hemorrhage. It was found that this is a sporadic disease that affected semi-confined dairy cattle. It was not possible to determine infectious etiology, so it is important to control environmental factors predisposing to the occurrence of the disease.

\section{ACKNOWLEDGMENTS}

The authors would like to thank Conselho Nacional de Desenvolvimento Científico e Tecnológico (CNPq), and Coordenação de Aperfeiçoamento de Pessoal de Nível Superior (CAPES) for the support in this study.

\section{BIOETHICS AND BIOSECURITY COMMITTEE APPROVAL DECLARATION}

We authors of the article entitled "Tracheal stenosis in a dairy cow in Southern Brazil" declare, for all due purposes, the project that gave rise to the present data of the same has not been submitted for evaluation to the Ethics Committee of the Universidade Federal do Rio Grande do Sul, but we are aware of the content of the Brazilian resolutions of the National Council for Control of Animal Experimentation - CONCEA "http://www. mct.gov.br/index.php/content/view/310553.html" if it involves animals. Thus, the authors assume full responsibility for the presented data and are available for possible questions, should they be required by the competent authorities.

\section{DECLARATION OF CONFLICT OF INTERESTS}

The authors declare no conflict of interest. The founding sponsors had no role in the design of the study; in the collection, analyses, or interpretation of data; in the writing of the manuscript, and in the decision to publish the results.

\section{AUTHORS' CONTRIBUTIONS}

All authors contributed equally for the conception and writing of the manuscript. All authors critically revised the manuscript and approved of the final version.

\section{REFERERENCES}

ANDREWS, G.A. \& KENNEDY, G.A. Respiratory diagnostic pathology. Veterinary clinics of North America: Food animal practice, vol.13, n.3, p.521-522, 1997. Available from: $\quad<$ https://www.sciencedirect.com/science/article/pii/ S0749072015303121?via\%3Dihub>. Accessed: Dec. 16, 2019. doi: 10.1016/S0749-0720(15)30312-1.

APLEY, M.D. \& FAIT, V.R. Feedlot therapeutics. Veterinary clinics of North America: Food animal practice, vol.14, n.2, p.297-298, 1998. Available from: $<$ https://www.sciencedirect.com/ science/article/pii/S0749072015302553?via\%3Dihub>. Accessed: Dec. 16, 2019. doi: 10.1016/S0749-0720(15)30255-3.

BÓ, G.A. et al. Pattern and manipulation of follicular development in Bos indicus cattle. Animal Reproduction Science, v.78, p.307326, 2003. Available from: <https:/www.sciencedirect.com/ science/article/pii/S0378432003000976?via\%3Dihub>. Accessed: Dec. 16, 2019. doi: 10.1016/S0378-4320(03)00097-6.

CASWELL, J.L. \& WILLIAMS, K.J. Respiratory system. In: JUBB et al. Pathology of Domestic Animals. Edinburgh: Elsevier-Saunders, 2016, 6th edition. vol. 2. p.482-483.

CLARK, T. Pathology of feedlot cattle. Proceedings of the WBC Congress, Québec, Canada, p.8, 2004. Available from: $<$ https:// pdfs.semanticscholar.org/c046/619d52da4eb67d736999129124e5 96f91d6e.pdf>. Accessed: Dec. 16, 2019.

ERICKSON, E.D. \& DOSTER, A.R. Tracheal stenosis in feedlot cattle. Journal of Veterinary Diagnostic Investigation, v.5, p.449-451, 1993. Available from: <https://journals.sagepub.com/ doi/pdf/10.1177/104063879300500328>. Accessed: Dec. 16, 2019. doi: $10.1177 / 104063879300500328$.

ESTEVES, P.A. Phylogenetic comparison of the carboxy-terminal region of glycoprotein $\mathrm{C}(\mathrm{gC})$ of bovine herpesviruses (BoHV) 1.1, 1.2 and 5 from South America (SA). Virus Research, v.131, p.16-22, 2008. Available from: <https://www.sciencedirect.com/ science/article/pii/S0168170207003012?via\%3Dihub>. Accessed: Dec. 16, 2019. doi: 10.1016/j.virusres.2007.08.004.

FERREIRA F. et al. Physiological parameters of crossbred cattle subjected to heat stress. Arquivos Brasileiros de 
Medicina Veterinária e Zootecnia, v.58, n.5, p.732-738, 2006. Available from: $<$ http://www.scielo.br/scielo.php?script $=$ sci abstract\&pid $=$ S0102-09352006000500005\&lng $=$ en \&nrm $=\overline{\mathrm{i}}$ so\&tlng $=\mathrm{pt}>$. Accessed: Dec. 16, 2019. doi: 10.1590/S010209352006000500005 .

GAGEA, M.I. et al. Diseases and pathogens associated with mortality in Ontario beef feedlots. Journal of Veterinary Diagnostic Investigation, vol.18, p.18-28, 2006. Available from: <https:// journals.sagepub.com/doi/pdf/10.1177/104063870601800104>. Accessed: Dec. 16, 2019. doi: 10.1177/104063870601800104.

GRIFFIN, D. Feedlot diseases. Veterinary clinics of North America: Food animal practice, vol. 14, n. 2, p. 206-207, 1998. Available from: $<$ https://www.sciencedirect.com/science/article/ pii/S0749072015302516>. Accessed: Dec. 16, 2019. doi: 10.1016 S0749-0720(15)30251-6.

HENDRICK, S. \& ABEYSEKARA, S. The epidemiology and treatment costs of lameness in Western Canadian feedlot cattle. Agriculture Development Fund. 2014. Available from: <http:// www.agriculture.gov.sk.ca/apps/adf/ADFAdminReport/20090355. pdf>. Accessed: Dec. 16, 2019.

INSTITUTO NACIONAL DE METEREOLOGIA (INMET). Available from $\quad<$ http://www.inmet.gov.br/portal/index. php?r=home/page\&page=rede_estacoes_auto_graf $>$. Accessed: Nov. 27, 2019

JENSEN, R. et al. Laryngeal diphtheria and papillomatosis in feedlot cattle. Veterinary Pathology, vol.18, p.143-150, 1981. Available from: <https://journals.sagepub.com/doi/pdf/1 0.1177/030098588101800201>. Accessed: Dec. 16, 2019. doi: $10.1177 / 030098588101800201$

MORAIS, D.A.E.F. et al. Annual variation of thyroid hormones and thermoregulatory characteristics of dairy cows in a hot environment. Revista Brasileira de Zootecnia, v.37, n.3, p.538-545, 2008. Available from: $<$ http://www.scielo.br/scielo.php?script=sci_artte
xt\&pid=S1516-35982008000300020>. Accessed: Dec. 16, 2019. doi: $10.1590 / \mathrm{S} 1516-35982008000300020$.

RADOSTITS, O. M. et al. Diseases of the respiratory system. In: Veterinary Medicine: a textbook of the diseases of cattle, sheep, pigs, goats and horses. Philadelphia: Saunders, 2000, 9th edition. p.468.

RINGS, D.M. Tracheal collapse. Veterinary clinics of North America: Food animal practice, vol.11, n.1, p.171-175, 1995. Available from: <https://www.sciencedirect.com/science/article/ abs/pii/S0749072015305156?via\%3Dihub>. Accessed: Dec. 16, 2019. doi: 10.1016/S0749-0720(15)30515-6.

RISSI, D.R. et al. Bovine herpesvirus-5 meningoencephalitis. Pesquisa Veterinária Brasileira, vol.27, n.7, p.251-260, 2007. Available from <http://www.scielo.br/pdf/pvb/v27n7/ a01v27n7.pdf $>$. Accessed: Mar, 24, 2020. doi: 10.1590/S0100736X2007000700001.

RISSI, D.R. et al. Epidemiology, clinical signs and distribution of brain lesions in cattle affected by bovine herpesvirus-5 meningoencephalitis. Pesquisa Veterinária Brasileira, vol.26, p.123-132, 2006. Availablefrom<http://www.scielo.br/pdf/pvb/ v26n2/a10v26n2.pdf>. Accessed: Mar. 24, 2020. doi: 10.1590/ S0100-736X2006000200010.

SZEREDI, L. et al. Acute Tracheal Oedema and Haemorrhage with FibrinonecroticTracheitis in Pigs - A Porcine Counterpart of Bovine Honker Syndrome? Journal of Comparative Pathology, vol. 152, p. 206-210, 2015. Available from: <https:/www.sciencedirect. com/science/article/pii/S0021997514001479?via\%3Dihub $>$. Accessed: Dec. 16, 2019. doi: 10.1016/j.jcpa.2014.10.003.

WATT, B.R. Collapse of the trachea in two calves. Australian Veterinary Journal, vol.60, n.10, p.39-31, 1983. Available from: $\quad<$ https://sci-hub.tw/10.1111/j.1751-0813.1983.tb02818. $\mathrm{x}>$. Accessed: Dec. 16, 2019. doi: 10.1111/j.1751-0813.1983. tb02818.x. 